\title{
Motivation Mechanism for Stimulating the Labor Potential
}

\author{
Iryna Koshkalda ${ }^{1}$, Oleksandr Kniaz ${ }^{1}$, Alona Ryasnyanska ${ }^{2} \&$ Viktoriya Velieva $^{3}$ \\ ${ }^{1}$ Department of Land Administration and Cadastre, Dokuchayev Kharkiv National Agrarian University, Kharkiv, \\ Ukraine \\ ${ }^{2}$ Department of Business, Trade and Exchange Activity, Petro Vasylenko Kharkiv National Technical University of \\ Agriculture, Kharkiv, Ukraine \\ ${ }^{3}$ Department of Statistics and Economic Analysis, Dokuchayev Kharkiv National Agrarian University, Kharkiv, \\ Ukraine
}

Correspondence: Iryna Koshkalda, Head of the Department of Land Administration and Cadastre, Dokuchayev Kharkiv National Agrarian University, Dokuchaievske-2, educ. campus KNAU, Kharkiv 62483, Ukraine. Tel: 380-50-323-5594. E-mail: irinavit1506@gmail.com

Received: June 23, 2020

Accepted: July 30, 2020

Online Published: August 14, 2020

doi:10.5430/rwe.v11n4p53

URL: https://doi.org/10.5430/rwe.v11n4p53

\begin{abstract}
The issue of motivating the labor personnel to work effectively has been studied. The views of the world scientific community on employee motivation have been analyzed. Motivation has been proved as a determining factor in ensuring the efficient and coordinated work of employees. The hypothesis has been put forward concerning the influence of such aspects of the labor activity as advanced training, a level of responsibility, work experience, promptness, quality of work, and labor intensity on the labor potential motivation. The degree of influence of these aspects of work is determined based on the method of pairwise comparisons. The reliability of the calculations was proved by determining the consistency of experts' opinions based on Spearman's rank correlation methodology.
\end{abstract}

Keywords: motivation, labor potential, human resources, labor resources

\section{Introduction}

Modern society proves that man is the nucleus of change and transformation. The much talked about sustainable development depends on human resources. The qualitative and quantitative characteristics of the economic, social and environmental components of sustainable development are directly dependent on the performance of human resources. Motivation is the lever of influence on a person. It is worth emphasizing that in recent decades there has been a commercialization of all life processes: the standard of living of the society, as well as the environmental state and food security, are directly dependent on the level of economic development in the countries across the world. Thus, the issues of increasing the efficiency of management at the enterprises of key sectors of the economy, agricultural enterprises, in particular, are of great importance. One of the main factors for improving the efficiency of the economic activity of enterprises is the level of personnel motivation, methods of stimulating work, and a decent reward to employees for their work.

The issue of searching for an effective system of motivation is not new to economic science; works by G. Gantt, F. Gilbert, A. Maslow, L. Porter, and P. Armstrong gave impetus to the development of motivational management worldwide. Their works present important theoretical, methodological and practical provisions intended to influence the implementation of the HRM process and the effectiveness of the motivational mechanism.

There are different definitions of motivation in world literature. Thus, Saraswathi refers to motivation as an employee's efforts to achieve the goals of the company and, indirectly, his own (Saraswathi S. A., 2011). Fuller defines motivation as intensity, direction, and persistence to achieve a specific goal (Fuller M.A., Valacich J.S.; George J.F., 2008). Kian, Yusoff, and Rajah identify three key elements for determining employee motivation: effort, purpose, and need (Kian T., Yusoff W., Rajah S., 2014). Wegner and Miller believe that motivation is an external factor that stimulates people to take certain actions to achieve a certain goal (More H.W., Wegner F.W., Miller L.S., 2003). Whiseand and Rush define motivation as the desire of a person to do something in such a way to meet their needs (Whiseand P., Rush G., 1988). White states that motivation can be objective, as well as subjective (White R.W., 1959). The subjective in this sense depends on each person, according to Amabile, because "individuals are 
intrinsically motivated when they seek enjoyment, interest, the satisfaction of curiosity, self-expression, or personal challenge in the work" (Amabile T.M., 1993). The objective motivation is linked to the environment a person interacts with. As Lunenburg states: "The engagement in the work to obtain some goal that is apart from the work itself' (LunenburgF., 2011).

Davidescu, Roman, Strat, and Mosora have employed a multi-level modeling approach employed to understand the determinants of work motivation, using individual factors, as described in Vroom's theory (as updated by Chan) and contextual factors, covered by three dimensions of sustainability. Besides, these scientists have concluded that job stability is an important factor that positively affects work motivation: in a sustainable working environment, people are more motivated if they have a stable, secure job (Davidescu A. \& Roman M. \& Strat V. \& Mosora M., 2019).

Baik, Song, and Hong developed the JD-R model. According to this model, three strategies are important: providing sufficient job resources, cultivating personal resources related to self-efficacy, and maintaining an appropriate level of job demands. This study demonstrated the importance of social, psychological, and physical resources in human resource development (HRD), providing managers and HRD practitioners with the means to help employees become more fully engaged in their work (Baik, Soo \& Song, Hae-Deok \& Hong, Ah., 2018).

Bigi, Greenan, Hamon-Cholet, and Lanfranchi have established that for workers to work effectively, work stability and social guarantees must be ensured. These researchers compared in the private sector and the state civil service the impacts of Information and Communication Technology and management changes on the evolution of these three dimensions of work experience. It was found that dissatisfied workers tend to leave their company while public agents are more stable even if they face more adverse conditions because of strong employment protection (Bigi, Maëlezig \& Greenan, Nathalie \& Hamon-Cholet, Sylvie \& Lanfranchi, Joseph, 2018). Clipa Anca \& Danileț, \& Andrei, exploring the role of negotiations in the process of forming and improving labor relations, concluded that "trust in the employer and the subjective value perceived by the employee in the negotiation process are thus prerequisites for the commitment to remain in an employment relationship since they influence both employee satisfaction and the employee's willingness to renegotiate in the future with the employer" (Clipa A.M., Clipa C.I., Danileț M., Andrei A.G., 2019).

Tovmasyan explored such a sphere of the economy as the tourism market in Armenia and concluded that the central role in the quality of labor resources belongs to the level of education and skills (Tovmasyan G., 2019). It is worth noting that the issue of innovation and the role of the work force in this area is relevant today. Many scholars have explored these issues; in particular, Mazur-Wierzbicka believes that the labor force is a key factor in innovative development (Mazur-Wierzbicka E., 2019).

Innovative approaches to the management of the labor force were studied by Gallo, Mihalcova, Vegsoova, Dzurov-Vargova, Busova, who, considering the case study of a healthcare facility in Slovakia, explored the factors that influence the efficiency of work of labor personnel (Gallo P., Mihalcova B., Vegsoova O., Dzurov-Vargova T \& Busova N., 2019).

Butko, Popelo, Pishenin studied innovations in personnel management in terms of European integration on the example of agribusiness in Ukraine. In particular, the authors allocated and emphasized the importance of the following components: production, finance, marketing, and transactions (Butko M., Popelo O., \& Pishenin I., 2019).

Anyway, we cannot but agree that the main thing in managing labor resources and in the effectiveness of their activities is motivation. Researchers are faced with the important issue of finding a motivation mechanism that can successfully stimulate labor personnel to work effectively (Perevozova I., Babenko V., Kondur O., Krykhovetska Z. and Daliak N., 2019). Thus, Ozsoy applied to practice a two-factor model of Herzberg's motivation. The theory suggests two mains distinctions in employee motivation (i.e., motivation factors and hygiene factors). Motivation factors are achievement, recognition, work itself, responsibility, advancement, and growth. Hygiene factors are company policy and administration, supervision, relationship with supervisor, working conditions, salary, and relationship with peers, personal relationship, relationship with subordinates, status, and security (Ozsoy E., 2019).

\section{Methodology}

The study was performed by the method of pairwise comparisons (correlation). The hypothesis of the research is to determine the degree of influence of such aspects of the labor activity as advanced training, a level of responsibility, work experience, promptness, quality of work, and labor intensity on the labor potential motivation. The expert group consisted of 26 respondents, who were the employees of the agricultural enterprises of the Kharkiv region. The next stage was to calculate the average weight of each aspect of the labor activity. The consistency of expert opinions was verified based on Spearman's rank correlation methodology. 


\section{Results and Discussion}

According to World Bank studies in more than 160 countries, significant economic achievements are $60 \%$ dependent on human resources. As early as 1990, a group of economists led by a Pakistani Mahbub-ul-Khak developed the Human Development Index (HDI) (until 2013, the Human Potential Development Index (HDI)), an integral indicator calculated annually for cross-national comparisons and measuring living standards, literacy, education, and longevity as the main characteristics of the human potential of the researched area. It is a standard tool for the overall comparison of the standard of living in different countries and regions. The index is published as part of the UNDP (UN Development Program) in human development reports. Thus, according to the 2019 report, in 2018, Norway, Switzerland, and Ireland were ranked first, second and third among 189 countries in the Human Development Index. The last in this list are African countries such as Chad, Central African Republic, and Niger. Ukraine ranks 88th.

Therefore, under modern conditions, the role of man in production has changed significantly: man is the most important element, as well as the main strategic resource of the production process at the enterprise. Investments in human resources become a long-term factor of competitiveness of the enterprise. One of the factors for the efficient use and development of the rural workforce is labor motivation. The main purpose of our research is to study the needs of employees in the labor sphere, motivation potential and the extent of its use. The complexity of the problem of motivation is that different people have a different pattern of needs, and the needs change over time and in different circumstances.

Consider motivation factors in terms of Ukraine. The method of pairwise comparisons (correlation) was used for the research. A qualitative comparison of two objects is considered easier and more reliable than expressing an advantage in a point reference or rating scale. The hypothesis of the research is to determine the degree of influence of such aspects of labor activity as advanced training, a level of responsibility, work experience, promptness, quality of work, and labor intensity on the labor potential motivation. The expert group consisted of 26 respondents, who were employees of the agricultural enterprises of the Kharkiv region.

In our case, detailed numerical information about the studied objects, i.e. aspects of labor activity, is not obligatory and the comparison is made on the principle of "more-less" or "better-worse", without specifying how many times, how more or how better. The result of such pair comparison of aspects of labor activity received from one expert is presented in the table (Table 1).

As table 1 shows, an expert analyzed five aspects of labor activity (advanced training, a level of responsibility, work experience, promptness, quality of work, and labor intensity). Digit 1 at the intersection of a table row and a column indicates the preference for the object in the row over the object, which code is written in the column; zero indicates the reverse. The resulting ordinal scale for this case is as follows: "work experience" > "advanced training" = "a level of responsibility" = "labor intensity" > "promptness, quality of work". Therefore, expert 1 considers "work experience" the most important of the proposed aspects of the labor activity, the least important is "promptness, quality of work", and "advanced training"; "a level of responsibility" and "work intensity" are of the same importance for him.

Table 1. Questionnaire responses obtained by the pairwise comparison method from Expert 1 regarding the degree of influence of the proposed aspects of the labor activity on the labor potential motivation

\begin{tabular}{|c|c|c|c|c|c|c|}
\hline Aspects of labor activity & 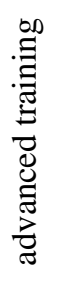 & 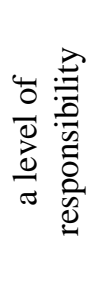 & 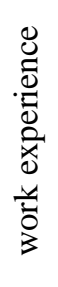 & 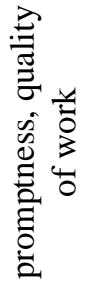 & 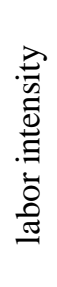 & Total \\
\hline advanced training & $\mathrm{x}$ & 1 & 0 & 1 & 0 & 2 \\
\hline a level of responsibility & 0 & $\mathrm{x}$ & 0 & 1 & 1 & 2 \\
\hline work experience & 1 & 1 & $\mathrm{x}$ & 1 & 1 & 4 \\
\hline promptness, quality of work & 0 & 0 & 0 & $\mathrm{x}$ & 1 & 1 \\
\hline labor intensity & 1 & 0 & 0 & 1 & $\mathrm{x}$ & 2 \\
\hline
\end{tabular}


Such questionnaires are received from all members of the expert group. In this case, there are 26 respondents. The results of the questionnaire by the method of pairwise comparisons are shown in Table 2.

Table 2. Results of the questionnaire by the method of pairwise comparisons on the degree of influence of the proposed aspects of the labor activity on the labor potential motivation

\begin{tabular}{|c|c|c|c|c|c|}
\hline \multirow[b]{2}{*}{ Experts } & \multicolumn{5}{|c|}{ Aspects of the labor activity } \\
\hline & $\begin{array}{c}\text { advanced } \\
\text { training }\end{array}$ & $\begin{array}{c}\text { a level of } \\
\text { responsibility }\end{array}$ & $\begin{array}{c}\text { work } \\
\text { experience }\end{array}$ & $\begin{array}{l}\text { promptness, } \\
\text { quality of work }\end{array}$ & labor intensity \\
\hline 1 & 2 & 2 & 4 & 1 & 2 \\
\hline 2 & 2 & 1 & 3 & 1 & 2 \\
\hline 3 & 2 & 2 & 2 & 2 & 2 \\
\hline 4 & 2 & 1 & 3 & 1 & 1 \\
\hline 5 & 1 & 1 & 2 & 1 & 1 \\
\hline 6 & 2 & 2 & 2 & 3 & 3 \\
\hline 7 & 1 & 2 & 3 & 4 & 2 \\
\hline 8 & 2 & 4 & 3 & 2 & 1 \\
\hline 9 & 1 & 1 & 2 & 1 & 1 \\
\hline 10 & 1 & 1 & 2 & 2 & 2 \\
\hline 11 & 1 & 2 & 3 & 1 & 2 \\
\hline 12 & 2 & 2 & 2 & 1 & 1 \\
\hline 13 & 3 & 1 & 4 & 1 & 1 \\
\hline 14 & 1 & 1 & 4 & 2 & 3 \\
\hline 15 & 1 & 3 & 4 & 1 & 1 \\
\hline 16 & 1 & 1 & 2 & 2 & 1 \\
\hline 17 & 1 & 1 & 3 & 2 & 1 \\
\hline 18 & 1 & 1 & 4 & 1 & 3 \\
\hline 19 & 2 & 2 & 4 & 3 & 2 \\
\hline 20 & 2 & 1 & 1 & 4 & 1 \\
\hline 21 & 2 & 2 & 2 & 3 & 1 \\
\hline 22 & 2 & 2 & 3 & 1 & 2 \\
\hline 23 & 3 & 1 & 3 & 2 & 2 \\
\hline 24 & 3 & 3 & 1 & 2 & 2 \\
\hline 25 & 4 & 1 & 4 & 1 & 2 \\
\hline 26 & 2 & 1 & 1 & 1 & 3 \\
\hline
\end{tabular}

The next step is to calculate the normed valuation provided by the $i$-th expert of the $j$-th factor $\left(W_{i j}\right)(1)$ :

$$
W_{i j}=\frac{\mathrm{C}_{i j}}{\sum_{j=1}^{n} \mathrm{C}_{i j}}
$$

where $C_{i j}$ is the valuation of the value of relative weight (in points) provided by the $i$-th expert of the $j$-th factor; $n$ is the number of factors being studied.

We calculate the normed valuation given by the 1-st expert of the 1-st factor $\left(W_{l l}\right)$ according to Table 2: 


$$
W_{11}=\frac{2}{\sum_{j=1}^{5}(2+2+4+1+2)}=0,182
$$

Similarly, the calculation is done on other factors and experts (Table 3).

Table 3. Results of the calculation of the normed valuation provided by the $i$-th expert of the $j$-th factor (Wij)

\begin{tabular}{|c|c|c|c|c|c|}
\hline \multirow[b]{2}{*}{ Experts } & \multicolumn{5}{|c|}{ Aspects of the labor activity } \\
\hline & $\begin{array}{c}\text { advanced } \\
\text { training }\end{array}$ & $\begin{array}{c}\text { a level of } \\
\text { responsibility }\end{array}$ & $\begin{array}{c}\text { work } \\
\text { experience }\end{array}$ & $\begin{array}{l}\text { promptness, } \\
\text { quality of work }\end{array}$ & labor intensity \\
\hline 1 & 0,182 & 0,182 & 0,364 & 0,091 & 0,182 \\
\hline 2 & 0,222 & 0,111 & 0,333 & 0,111 & 0,222 \\
\hline 3 & 0,200 & 0,200 & 0,200 & 0,200 & 0,200 \\
\hline 4 & 0,250 & 0,125 & 0,375 & 0,125 & 0,125 \\
\hline 5 & 0,167 & 0,167 & 0,333 & 0,167 & 0,167 \\
\hline 6 & 0,167 & 0,167 & 0,167 & 0,250 & 0,250 \\
\hline 7 & 0,083 & 0,167 & 0,250 & 0,333 & 0,167 \\
\hline 8 & 0,167 & 0,333 & 0,250 & 0,167 & 0,083 \\
\hline 9 & 0,167 & 0,167 & 0,333 & 0,167 & 0,167 \\
\hline 10 & 0,125 & 0,125 & 0,250 & 0,250 & 0,250 \\
\hline 11 & 0,111 & 0,222 & 0,333 & 0,111 & 0,222 \\
\hline 12 & 0,250 & 0,250 & 0,250 & 0,125 & 0,125 \\
\hline 13 & 0,300 & 0,100 & 0,400 & 0,100 & 0,100 \\
\hline 14 & 0,091 & 0,091 & 0,364 & 0,182 & 0,273 \\
\hline 15 & 0,100 & 0,300 & 0,400 & 0,100 & 0,100 \\
\hline 16 & 0,143 & 0,143 & 0,286 & 0,286 & 0,143 \\
\hline 17 & 0,125 & 0,125 & 0,375 & 0,250 & 0,125 \\
\hline 18 & 0,100 & 0,100 & 0,400 & 0,100 & 0,300 \\
\hline 19 & 0,154 & 0,154 & 0,308 & 0,231 & 0,154 \\
\hline 20 & 0,222 & 0,111 & 0,111 & 0,444 & 0,111 \\
\hline 21 & 0,200 & 0,200 & 0,200 & 0,300 & 0,100 \\
\hline 22 & 0,200 & 0,200 & 0,300 & 0,100 & 0,200 \\
\hline 23 & 0,273 & 0,091 & 0,273 & 0,182 & 0,182 \\
\hline 24 & 0,273 & 0,273 & 0,091 & 0,182 & 0,182 \\
\hline 25 & 0,333 & 0,083 & 0,333 & 0,083 & 0,167 \\
\hline 26 & 0,250 & 0,125 & 0,125 & 0,125 & 0,375 \\
\hline
\end{tabular}

To calculate the average weight of each factor $(\mathrm{Wj})$ the formula is used:

$$
W_{j}=\frac{\sum_{i=1}^{m} W_{i j}}{m},
$$

where $W i j$ is the normed valuation given by the $i$-th expert of the $j$-th factor; $m$ is the number of experts.

Thus, the average weight of such an aspect of work as "advanced training" is:

$$
W_{1}=\frac{\sum_{i=1}^{m} 0,182+0,222+0,200+\cdots+0,273+0,333+0,250}{26}=0,187
$$


Similarly, having calculated other factors, we find that the average weights of such aspects of the labor activity as "a level of responsibility" is 0.166 , "work experience" -0.285 , "promptness, quality of work" -0.183 , "work intensity" - 0.180. Thus, we can conclude that under current conditions of Ukrainian agricultural enterprises, the labor personnel believes that such an indicator as "work experience" is of the greatest importance, while other factors indirectly influence the level of their motivation.

The next step is to check the consistency of the experts' opinions, which is conducted based on Spearman's rank correlation methodology. To do this, the sample coefficients of the pairwise Spearman rank correlation should first be found. To do this, the formula is used (3):

$$
\rho_{\alpha \beta}=1-\frac{\sum_{j=1}^{n} \Psi_{j}^{n}}{\frac{1}{6}\left(n^{n}-n\right)-\frac{1}{12}\left(T_{\alpha \alpha}-T_{\beta}\right)}
$$

where $\rho_{\alpha \beta}$ is the coefficient of pairwise rank correlation between the $i$-th and the $j$-th expert; $\Psi_{j}$ is the difference in

the modulus of the value of the rankings of the $j$-th factor set by experts $\alpha$ and $\beta$, i.e. $\Psi_{\mathrm{j}}=\left|R_{\alpha j}-R_{\beta j}\right|$ (4) ; $T_{\alpha}, T_{\beta}$ are the indicators of the related rankings of expert estimates $\alpha$ and $\beta$, which are determined by the formula; $\mathrm{T}_{j}=\sum_{l=1}^{L}\left(t_{l}^{3}-t_{l}\right),(5) ; t_{l}$ is the number of related ranks in each group; $l$ is the number of groups of related (equal) ranks.

The pairwise rank correlation coefficient is calculated for the first two experts, though first, such an indicator as a related rank should be defined. The results of the calculation of this indicator are given in Table 4 .

Table 4. Standardized ranks of questionnaire indicators

\begin{tabular}{|c|c|c|c|c|c|}
\hline \multirow[b]{2}{*}{ Experts } & \multicolumn{5}{|c|}{ Aspects of the labor activity } \\
\hline & $\begin{array}{l}\text { advanced } \\
\text { training }\end{array}$ & $\begin{array}{l}\text { a level of } \\
\text { responsibility }\end{array}$ & $\begin{array}{c}\text { work } \\
\text { experience }\end{array}$ & $\begin{array}{l}\text { promptness, } \\
\text { quality of work }\end{array}$ & labor intensity \\
\hline 1 & 3,5 & 3,5 & 1 & 5 & 3,5 \\
\hline 2 & 2,5 & 4,5 & 1 & 4,5 & 2,5 \\
\hline 3 & 5 & 5 & 5 & 5 & 5 \\
\hline 4 & 2 & 4 & 1 & 4 & 4 \\
\hline 5 & 3,5 & 3,5 & 1 & 3,5 & 3,5 \\
\hline 6 & 4 & 4 & 4 & 1,5 & 1,5 \\
\hline 7 & 5 & 3,5 & 2 & 1 & 3,5 \\
\hline 8 & 3,5 & 1 & 2 & 3,5 & 5 \\
\hline 9 & 3,5 & 3,5 & 1 & 3,5 & 3,5 \\
\hline 10 & 4,5 & 4,5 & 2 & 2 & 2 \\
\hline 11 & 4,5 & 2,5 & 1 & 4,5 & 2,5 \\
\hline 12 & 2 & 2 & 2 & 4,5 & 4,5 \\
\hline 13 & 2 & 4 & 1 & 4 & 4 \\
\hline 14 & 4,5 & 4,5 & 1 & 3 & 2 \\
\hline 15 & 4 & 2 & 1 & 4 & 4 \\
\hline 16 & 4 & 4 & 1,5 & 1,5 & 4 \\
\hline 17 & 4 & 4 & 1 & 2 & 4 \\
\hline 18 & 4 & 4 & 1 & 4 & 2 \\
\hline 19 & 4 & 4 & 1 & 2 & 4 \\
\hline 20 & 2 & 4 & 4 & 1 & 4 \\
\hline
\end{tabular}




\begin{tabular}{cccccc}
\hline 21 & 4 & 4 & 4 & 1 & 5 \\
\hline 22 & 4 & 4 & 1 & 5 & 4 \\
\hline 23 & 1,5 & 5 & 1,5 & 3,5 & 3,5 \\
\hline 24 & 1,5 & 1,5 & 5 & 3,5 & 3,5 \\
\hline 25 & 1,5 & 4,5 & 1,5 & 4,5 & 3 \\
\hline 26 & 2 & 4 & 4 & 4 & 1 \\
\hline
\end{tabular}

For convenience and clarity, the numerator of formula (3) is defined in Table 5.

Table 5. Calculation of the squared difference between the values of the rankings of two experts

\begin{tabular}{|c|c|c|c|c|}
\hline \multirow{2}{*}{$\begin{array}{c}\text { Aspects of the labor } \\
\text { activity }\end{array}$} & \multicolumn{2}{|c|}{ Experts' ranking } & \multirow{2}{*}{$\left|R_{1 j}-R_{2 j}\right|$} & \multirow{2}{*}{$\left|\boldsymbol{R}_{1 j}-\boldsymbol{R}_{2 j}\right|^{2}$} \\
\hline & $R_{1 j}$ & $\boldsymbol{R}_{2 j}$ & & \\
\hline advanced training & 3,5 & 2,5 & 1 & 1 \\
\hline $\begin{array}{c}\text { a level of } \\
\text { responsibility }\end{array}$ & 3,5 & 4,5 & 1 & 1 \\
\hline work experience & 1 & 1 & 0 & 0 \\
\hline $\begin{array}{c}\text { promptness, quality } \\
\text { of work }\end{array}$ & 5 & 4,5 & 0,5 & 0,25 \\
\hline labor intensity & 3,5 & 2,5 & 1 & 1 \\
\hline Total & & & & 3,25 \\
\hline
\end{tabular}

The related (standardized) ranks for the first two experts are:

$$
\begin{gathered}
\mathrm{T}_{1}=3^{3}-3=24 \\
\mathrm{~T}_{2}=\left(2^{3}-2\right)+\left(2^{3}-2\right)=12
\end{gathered}
$$

The coefficient of the pairwise rank correlation between the valuations of the 1-st and 2-nd experts according to the formula (3) is:

$$
\rho_{\alpha \beta}=1-\frac{3,25}{\frac{1}{6}\left(5^{3}-5\right)-\frac{1}{12}(24-12)}=0,171
$$

Similarly, the coefficients of pairwise rank correlation between the estimates for all possible pairs of elements are calculated (Table 6).

The coefficient of pairwise rank correlation is within $-1 \leq \rho \leq+1$. If $\rho=1$, then it corresponds to the full coincidence of the opinions of two experts, the value of $\rho=(-1)$ means that the experts' opinions regarding the ranking of the

\begin{tabular}{|c|c|c|c|c|c|c|c|c|c|c|c|c|c|c|c|c|c|c|c|c|c|c|c|c|c|}
\hline & 12 & 3 & 4 & 5 & 6 & 7 & 8 & 9 & 10 & 11 & 12 & 13 & 14 & 15 & 16 & 17 & 18 & 19 & 20 & 21 & 22 & 23 & 24 & 25 & 26 \\
\hline 1 & 10,171 & 0,247 & 0,258 & 0,412 & 0,432 & 0,469 & 0,471 & 0,347 & 0,568 & 0,478 & 0,412 & 0,459 & 0,625 & 0,645 & 0,566 & 0,713 & 0,852 & 20,659 & 0,636 & 60,526 & 0,245 & 0,452 & 0,369 & 0,348 & 0,521 \\
\hline 2 & 1 & 0,404 & 0,367 & 0,487 & 0,426 & 0,389 & 0,378 & 0,243 & 0,365 & 0,447 & 0,487 & 0,491 & 0,485 & 0,678 & 0,425 & 0,522 & 0,454 & 40,462 & 0,499 & 90,481 & 0,415 & 0,463 & 0,371 & 0,402 & 0,385 \\
\hline 3 & & 1 & 0,335 & 0,348 & 0,472 & 0,254 & 0,301 & 0,453 & 0,436 & 0,431 & 0,485 & 0,447 & 0,503 & 0,522 & 0,417 & 0,398 & 0,478 & 80,456 & 0,509 & 90,367 & 0,337 & 0,245 & 0,306 & 0,418 & 0,434 \\
\hline 4 & & & 1 & 0,337 & 0,388 & 0,374 & 0,405 & 0,414 & 0,452 & 0,476 & 0,435 & 0,472 & 0,438 & 0,446 & 0,489 & 0,474 & 0,451 & 10,423 & 0,429 & 90,428 & 0,403 & 0,368 & 0,396 & 0,390 & 0,411 \\
\hline 5 & & & & 1 & 0,406 & 0,463 & 0,428 & 0,438 & 0,478 & 0,365 & 0,391 & 0,348 & 0,352 & 0,249 & 0,347 & 0,447 & 0,487 & 70,491 & 0,485 & 50,352 & 0,249 & 0,347 & 0,447 & 0,352 & 0,249 \\
\hline
\end{tabular}
importance of factors (parameters, directions) are mutually opposite.

Table 6. Matrix of pairwise Spearman rank correlation coefficients 


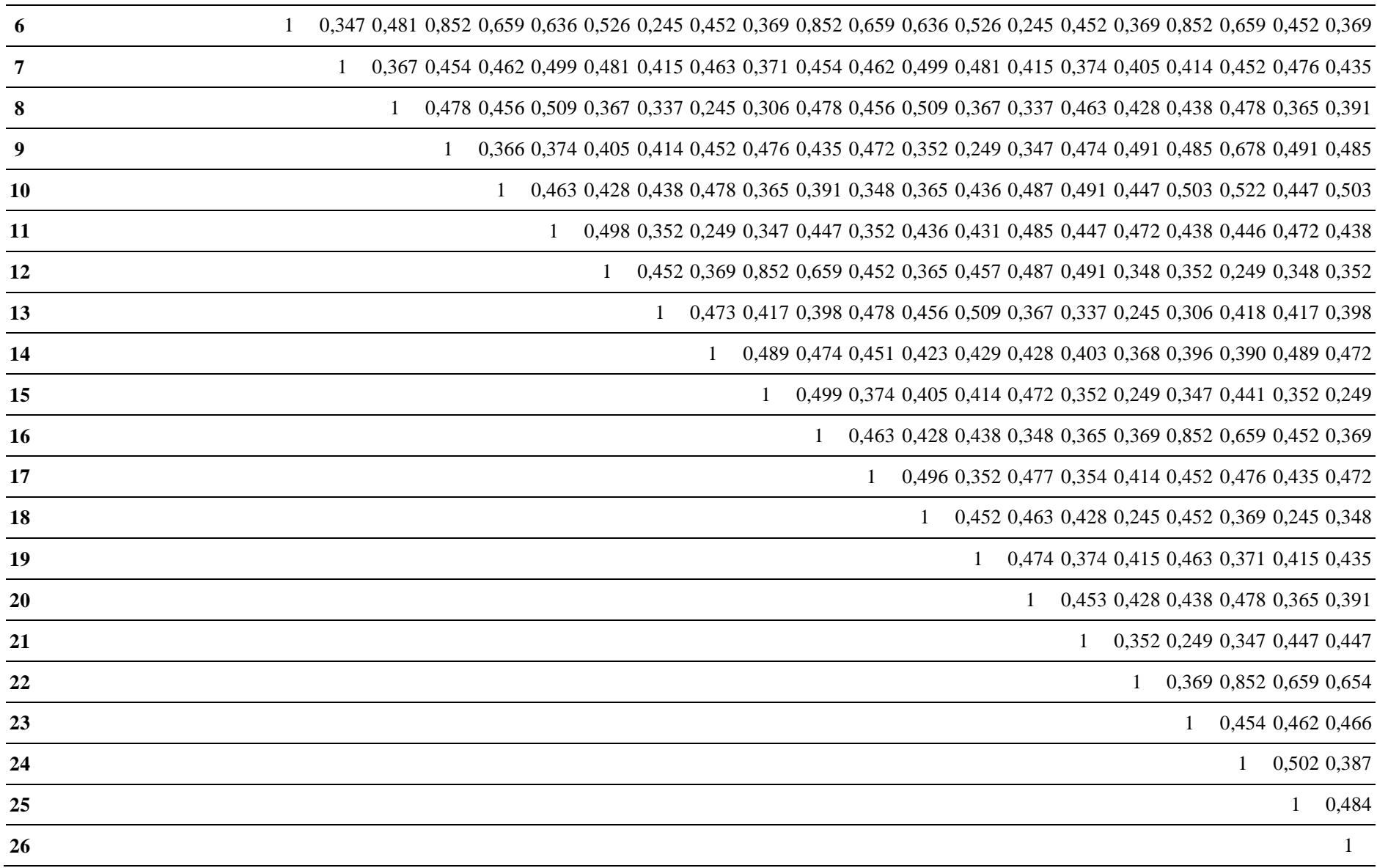

The values of the pairwise rank correlation coefficients show that the degree of coincidence of opinions between expert pairs is quite high, which indicates a sufficiently high degree of consistency of experts' opinions and the reliability of the results of the study, as well.

\section{Conclusion}

The effective functioning of an agricultural enterprise, ensuring its competitiveness is largely due to how efficiently the personnel is used. Motivation is a key factor in ensuring the effective and coordinated work of employees. Considering this, it is necessary to make gradual qualitative and dynamic changes in the agricultural sector of the economy. In its turn, this requires modern approaches to the formation of the personnel motivation mechanism of agricultural enterprises.

The hypothesis of the study was confirmed based on the method of pairwise comparisons by calculating the degree of influence of the proposed aspects of the labor activity and the average weight of each of these aspects on the labor potential motivation. Thus, we can conclude that under current conditions of Ukrainian agricultural enterprises, the labor personnel believes that such an indicator as "work experience" is of the highest importance, while other factors indirectly influence their level of motivation.

\section{References}

Amabile, T. M. (1993). Motivational Synergy: Toward new Conceptualizations of Intrinsic and Extrinsic Motivation in the Workplace. Hum. Resour. Manag. Rev., 3, 185-201. https://doi.org/10.1016/1053-4822(93)90012-S

Baik, S., Song, H-D., \& Hong, A. (2018). Craft Your Job and Get Engaged: Sustainable Change-Oriented Behavior at Work. Sustainability, 10, 4404. https://doi.org/10.3390/su10124404

Bigi, M., Greenan, N., Hamon-Cholet, S., \& Lanfranchi, J. (2018). The Human Sustainability of ICT and Management Changes: Evidence for the French Public and Private Sectors. Sustainability, 10, 3570. https://doi.org/10.3390/su10103570 
Butko, M., Popelo, O., \& Pishenin, I. (2019). Innovations in Human Resources Management in Eurointegration Conditions: Case for Ukrainian Agro-Industrial Complex. Marketing and Management of Innovations, 2, 74-82. https://doi.org/10.21272/mmi.2019.2-07

Clipa, A. M., Clipa, C. I., Danileț, M., \& Andrei, A. G. (2019). Enhancing Sustainable Employment Relationships: An Empirical Investigation of the Influence of Trust in Employer and Subjective Value in Employment Contract Negotiations. Sustainability, 11, 4995. https://doi.org/10.3390/su11184995

Davidescu, A., Roman, M., Strat, V., \& Mosora, M. (2019). Regional Sustainability, Individual Expectations and Work Motivation: A Multilevel Analysis. Sustainability, 11, 3331. https://doi.org/10.3390/su11123331

Fuller, M. A., Valacich, J. S., \& George, J. F. (2008). Information Systems Project Management: A Process and Team Approach, p. 417. Upper Saddle River; Pearson Prentice Hall: New Jersey, NJ, USA.

Gallo, P., Mihalcova, B., Vegsoova, O., Dzurov-Vargova, T., \& Busova, N. (2019). Innovative Trends in Human Resources Management: Evidence for the Health Care System. Marketing and Management of Innovations, 2, 11-20. https://doi.org/10.21272/mmi.2019.2-01

Kian, T., Yusoff, W., \& Rajah, S. (2014). Motivation for generations' cohorts: An organizational justice perspective. Int. J. Manag. Sci, 11, 536-542.

Lunenburg, F. (2011). Expectancy Theory of Motivation: Motivating by Altering Expectations. Int. J. Manag. Bus. Adm., $15, \quad 1 . \quad$ Retrieved from http://www.nationalforum.com/Electronic\%20Journal\%20Volumes/Luneneburg,\%20Fred\%20C\%20Expectanc y\%20Theory\%20\%20Altering\%20Expectations\%20IJMBA\%20V15\%20N1\%202011.pdf

Mazur-Wierzbicka, E. (2019). Human Resources as Fundamental Element Determining the Development of Innovation. Marketing and Management of Innovations, 1, 335-356. https://doi.org/10.21272/mmi.2019.1-28

More, H. W., Wegner, F. W., \& Miller, L. S. (2003). Effective police supervision, p. 648. Cincinnati: Anderson Publishing Co.: Cincinnati, OH, USA.

Ozsoy, E. (2019). An Empirical Test of Herzberg's Two-Factor Motivation Theory. Marketing and Management of Innovations, 1, 11-20. https://doi.org/10.21272/mmi.2019.1-01

Perevozova, I., Babenko, V., Kondur, O., Krykhovetska, Z., \& Daliak, N. (2019). Financial support for the competitiveness of employees in the mining industry. SHS Web of Conferences, 65, 1-6. https://doi.org/10.1051/shsconf/20196501001

Perevozova, I., Daliak, N., \& Babenko, V. (2019). Modeling of Financial Support for the Competitiveness of Employees in the Mining Industry. CEUR Workshop Proceedings, 2422, pp. 444-454. Retrieved from http://ceur-ws.org/Vol-2422/paper36.pdf

Saraswathi, S. A. (2011). Study on Factors that Motivate IT and Non-IT Sector Employees: A Comparison. Int. J. Res. Comput. Appl. Manag, 1, 72-77.

Tovmasyan, G. (2019). Exploring the Requirements of Tourism Labour Market in Armenia. Marketing and Management of Innovations, 1, 96-104. https://doi.org/10.21272/mmi.2019.1-08

Whiseand, P., \& Rush, G. (1988). Supervising Police Personnel: Back to Basics, p. 280. Prentice Hall: New Jersey, NJ, USA.

White, R. W. (1959) Motivation Reconsidered: The Concept of Competence. Psychol. Rev., 66, 297-333. https://doi.org/10.1037/h0040934

\section{Copyrights}

Copyright for this article is retained by the author(s), with first publication rights granted to the journal.

This is an open-access article distributed under the terms and conditions of the Creative Commons Attribution license (http://creativecommons.org/licenses/by/4.0/). 